\title{
Identification And Quantification Of Hydrocarbons Produced From The Acid-Pretreated Kitchen Waste By Using Fungal And Bacterial Strains
}

Nayab Zahara ( $\sim$ nayab.zahra@uettaxila.edu.pk)

University of Engineering and Technology, Taxila https://orcid.org/0000-0003-0506-8592

Muhammad Irfan Jalees

University of Engineering and Technology, Lahore

Muhammad Umar Farooq

University of Engineering and Technology, Lahore

Arfa lqbal

University of Engineering and Technology, Lahore

Sadaan Umais Malik

University of Engineering and Technology, Taxila

\section{Research Article}

Keywords: Fermentation, Aspergillus Niger, Escherichia coli, Lacto-bacillus

Posted Date: April 26th, 2021

DOI: https://doi.org/10.21203/rs.3.rs-415818/v1

License: (9) This work is licensed under a Creative Commons Attribution 4.0 International License.

Read Full License 


\section{Abstract}

This study was conducted to identify and quantify hydrocarbons produced during bio-fuel production using kitchen waste (KW). KW is a complex mixture of hardly digestible compounds, mainly lignin, cellulose and hemicellulose, and easily digestible compounds, mostly starchy materials. Therefore, KW has a high potential for the production of biofuel after the chemical hydrolysis of lignocellulose, starch and carbohydrates. In this study, after the physically pretreatment (dried and crushed) of KW, dilute-acid hydrolysis was used for the hydrolysis of lignocellulose and starchy materials, eliminating the enzymes requirement. The dilute acid hydrolysis was conducted with 1,3 and $5 \%(\mathrm{w} / \mathrm{w})$ sulfuric acid at 90 and $120^{\circ} \mathrm{C}$ for $30,60,90$ and $120 \mathrm{~min}$. The hydrolysis with $5 \%$ acid at $120^{\circ} \mathrm{C}$ for 120 min resulted in the hydrolysate with the highest reducing sugar concentration of $97.917 \pm 0.5 \mathrm{~g} / \mathrm{kg}$ and Energy of $1.567 \pm$ $0.008 \mathrm{MJ} / \mathrm{kg}$. The reducing sugars were used as substrate in fermentation by fungal strain Aspergillus niger, bacterial strains Lacto-bacillus and Escherichia coli, to produce hydrocarbons. The fermented product was quantified after every day till the fermentation time is over i.e. no more products were formed. Biofuel production from Aspergillus niger, Escherichia coli and Lacto-bacillus was $64 \%, 45 \%$ and $50 \%$ after $72 \mathrm{hr}$. Fermented product contains mainly hydrocarbons as identified by GC-MS analysis. Calorific value of sample and biofuel determined on Differential Scanning Calorimetry were $0.6 \mathrm{MJ} \mathrm{kg}^{-1}$ for sample before fermentation and $3.56 \mathrm{MJ} \mathrm{kg}^{-1}, 3.33 \mathrm{MJ} \mathrm{kg}^{-1}$ and $2.67 \mathrm{MJ} \mathrm{kg}^{-1}$ for KW fermented by Aspergillus niger, Escherichia coli and Lacto-bacillus, respectively. Hence, maximum of $64 \%$ reducing sugars were converted into hydrocarbons (biofuel) after fermentation by Aspergillus niger.

\section{Novelty}

Traditionally the Biofuel production is associated with open fermentation which is good in producing furfurals compounds but bad for good yields of hydrocarbons. For better quality and quantity of Hydrocarbons, optimized conditions along with fermentation was performed in this study. The results not only indicated better quality but also convert macromolecules to hydrocarbons with good calorific values. Comparison of results of this study with traditional fermentation to produce biofuel showed better of study results (Quality and Quantity of Hydrocarbons) than the previous results available in literature.

\section{Introduction}

Abundant usage of fossil fuel for transportation has adverse effects on environment, not only climate changes are visible, but depletion of fossil fuel is also a threat. This leads to use of alternative energy recourses. Environmental friendly and renewable fuel always attracts attention for the protection of the environment and supplies our needs by reducing dependence on non-renewable energy sources and petroleum [1]. Many countries, including Pakistan, are moving towards bio-fuel to reduce the emission of gasses and economic burden (imported petroleum for transportation and industrial plants).

Bio-fuel, which is an attractive alternative fuel, has the potential to meet the increasing demand of energy for different industrial processes, power generation and transportation [2]. Biofuel may be produced by 
food crops like sugar beet and rapeseed (1st generation) and nonedible byproduct of food crops e.g. agricultural residue, grass, sawdust, wood chips, waste cooking oil and municipal solid waste (MSW) etc. (2nd generation) [3]. In many countries, biofuel is produced from sugarcane and approximately $60 \%$ of global ethanol production based on this raw material while in United States $90 \%$ ethanol is produced from corn [4]. Many other sources of biofuel production are also known e.g. starch, palm oil [5], canola oil [6], animal fat [7], waste cooking oil [8], wheat straw [9], rice husk [10] and algae [11]. Moreover, production of biofuel from food source like sugar and corn cause increase in the crop price. Therefore, it is essential to research inexpensive and alternative biomass for ethanol production at a reduced cost. This issue turned the concern of researchers toward Municipal Solid Waste (MSW) as a raw material to produce biofuel.

Kitchen waste (KW) is a major portion of MSW and it is disposed of from restaurants, hotels, industrial and household kitchen at increasing amount all over the world. In Pakistan $90 \%$ of the collected waste goes for open dumping and cause environmental pollution. About 18,113 tons per day KW produced in Pakistan that is approximately $30.7 \%$ of municipal solid waste if treated or used properly then we can save our mother land from pollution $[12,13]$. Current practices for KW treatment involves composting, incineration, anaerobic digestion, land filling, open dumping as well as drying for animal feed $[14,15]$. Composting of KW provides a valuable soil conditioner and it reduces the mass and volume of waste as well. As KW has high moisture content so causes unusual level of leachate in composting that affects the performance of whole process by dropping oxygen availability and weak the strength of pile. KW can be utilized as an animal feed but due to its high moisture content and variable composition which favors microbial contamination it can be environmental unfriendly [14]. Incineration of solid waste causes emission of noxious gases and dioxins that are source of air pollution [16]. Landfill that is an engineered practice for waste disposal also causes serious environmental pollution. Its gas emissions are one of the largest anthropogenic sources of methane (cause of air pollution and ultimately global warming) especially because of KW. Leachate production from landfills is another serious environmental issue that causes ground water pollution and soil contamination with dangerous chemicals [17].

The biomass, in case of $\mathrm{KW}$, has a great potential to be used as sustainable energy source if converted to ethanol or another biofuel, while simultaneously treating kitchen waste. $\mathrm{KW}$ is primarily composed of cellulose (insoluble carbohydrate), hemicelluloses, lignin, proteins, fat, soluble sugars such as glucose, fructose and sucrose. Cellulose, glycogen and starch components of kitchen waste can be hydrolyzed to monomeric sugars. Therefore, due to abundant source of fermentable carbohydrates this sugar can be used as a substrate in microbial fermentation for the production of useful products such as biofuel [16, 18]. Young et. al [19] used food residue for ethanol production and maximum yield of $25 \mathrm{~g} / \mathrm{L}$ ethanol per $100 \mathrm{~g} / \mathrm{L}$ food residues was achieved using Saccharomyces cerevisiae. In another study it has been reported that hydrothermal pretreatment enhanced the $13.16 \%$ of ethanol production levels and 107.58 $\mathrm{g} / \mathrm{kg}$ of final ethanol yield was achieved using household food waste [20]. However, in the literature there are very few studies on the utilization of KW for the production of ethanol. 
The production of biofuel from biomass includes two main processes: hydrolysis of polysaccharide sugars into reducing sugars and fermentation of the reducing sugars to biofuel [21]. The conventional methods for hydrolysis process are acid hydrolysis and enzymatic hydrolysis. Dilute acid hydrolysis is successful for pretreatment of biomass. High reaction rates can be achieved by the dilute sulfuric acid pretreatment and it significantly improves hydrolysis of cellulose and glycogen [22]. Moreover, dilute acid hydrolysis is favorable at high temperature [23]. Dilute acid hydrolysis of KW converts polysaccharides into reducing sugars like sucrose and fructose [24]. These can be converted into valuable products such as hydrocarbons (HC's), Lactic Acid (LA) and Ethanol (ET) after microbial and fungal fermentation [3]. Yanuar et. al. investigated that $87-90 \mathrm{~g} / \mathrm{L}$ sugar concentration from hydrolysate was achieved at optimum conditions using lignocellulose biomass [25]. Several microbial species have the ability to ferment the hydrolysate of KW into biofuel. Aspergillus Niger, Lacto-bacillus and Escherichia coli are commonly used microbial strains in fermentation of biomass as these ferment the hexose sugars in to high ethanol yield [26]. Published studies have reported ethanol production from agro-industrial biomass using Aspergillus Niger and Trichoderma reesei [27]. Bruce et al. reported ethanol production from lignocellulose biomass using Escherichia coli [28]. Moreover, there are only few studies in the literature of microorganisms grown in monoculture on $\mathrm{KW}$ hydrolysates with the aim of producing renewable chemicals or biofuels. Usually, conversion of biofuel from KW is performed using open fermentation. Open fermentation has reduced production of furfural compounds which is inhibitor for bacterial growth $[29,30]$ but produces less hydrocarbons as macromolecules are difficult to ferment. To increase the quantity and quality of hydrocarbon produced as biofuel, this study was performed. The aim of this study was to investigate the effect of hydrolysis temperature, hydrolysis reaction time and acid concentration toward reducing sugar recovery from $\mathrm{KW}$. The acid hydrolysate produced after acid hydrolysis of $\mathrm{KW}$ was fermented by Aspergillus Niger, Lacto-bacillus and Escherichia coli for biofuel production and production of biofuel from these strains was compared. Moreover, the quantity and quality of produced hydrocarbons were analyzed on GC-MS and calorimeter.

\section{Materials And Methods}

\subsection{Microorganism and Inoculum preparation}

Aspergillus Niger FCBP-0198, Lacto-bacillus FCBP-0004 and Escherichia coli FCBP-0011 purchased from Punjab University fungal bank, Lahore Pakistan, were used in fermentation. Fungus was grown with 20g/L Malt extract (CM0059) and 20g/L Agar (CM0463). The culture media for Aspergillus Nigerwas sterilized at $121^{\circ} \mathrm{C}, 15 \mathrm{psi}$ for $15 \mathrm{~min}$ in an autoclave. For inoculum preparation, fungus was inoculated to $20 \mathrm{ml}$ of Maltextract and Agar media and been put to an incubator for $5-7$ days at $25^{\circ} \mathrm{C}$ to $27^{\circ} \mathrm{C}$. Lactobacillus was grown with 20g/L Malt extract (CM0059) and 20g/L Agar (CM0463) and media was sterilized in an autoclave at $121^{\circ} \mathrm{C}, 15 \mathrm{psi}$ for $15 \mathrm{~min}$. For inoculum preparation, bacteria was inoculated to $20 \mathrm{ml}$ of Maltextract and Agar media and been put to an incubator for $24 \mathrm{~h}$ at $35^{\circ} \mathrm{C}$. While for Escherichia coli, bacteria was grown with $5 \mathrm{~g} / \mathrm{L}$ yeast extract (LP0021), 10g/L tryptone (LP0042), 10g/L $\mathrm{NaCl}$ and $20 \mathrm{~g} / \mathrm{L} \mathrm{Agar}(\mathrm{CM} 0463)$ and media was sterilized in an autoclave at $121^{\circ} \mathrm{C}, 15 \mathrm{psi}$ for $15 \mathrm{~min}$. For 
inoculum preparation, bacteria was inoculated to $20 \mathrm{ml}$ of media and been put to an incubator for $24 \mathrm{~h}$ at $35^{\circ} \mathrm{C}$. All growth media were purchased from Merck Private Ltd., Pakistan. All cultures were preserved at $4^{\circ} \mathrm{C}$ to maintain viability.

\subsection{Raw Material and Pretreatment}

The KW utilized in this present research work was collected from houses, restaurants and cafeterias (Lahore, Pakistan) in summertime. The composition of KW was uncooked vegetables and fruits $(51 \%)$, cooked meat (16\%), uncooked meat (15\%), bread (2\%), tea leaves (5\%), egg shell (6\%), miscellaneous (5\%). Mixed KW was dried using Laboratory hot air oven (Wise cube WON-105) at $55 \pm 2^{\circ} \mathrm{C}$ for $48 \mathrm{~h}$ or more, until constant weight and then was ground in a laboratory grinder to achieve fine particles size of $0.45 \mathrm{~mm}$ to $1 \mathrm{~mm}$ by using a sieve of $200-400$ micron and to increase the surface area of particles. To maintain its physicochemical characteristics during the whole period it was stored at $-20^{\circ} \mathrm{C}$. The characteristics of the KW used in this present study are presented in Table 1. The dry mass of KW was mainly composed of cellulose, hemicellulose, starch sugars, protein and fat, which could be considered as a suitable biomass for ethanol production. These characteristics of KW were very similar to other studies that have been reported [31] [32] [33].

Table 1

Composition of kitchen waste

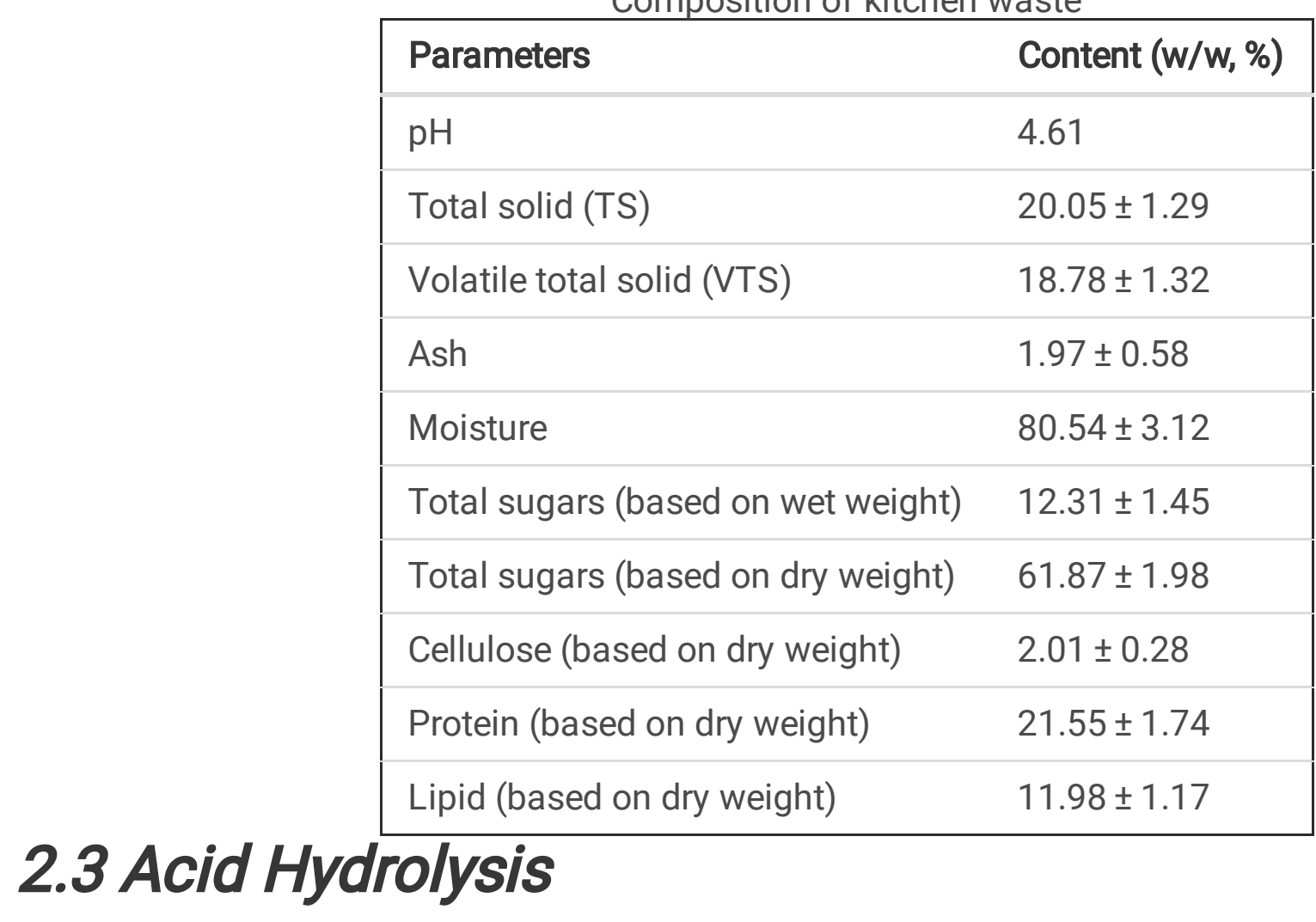

Acid hydrolysis was performed to produce soluble reducing sugars from $\mathrm{KW}$. The dilute acid hydrolysis of $\mathrm{KW}$ with $1 \%, 3 \%$ and $5 \%(\mathrm{w} / \mathrm{w})$ sulfuric acid was conducted at two different temperatures $\left(90\right.$ and $\left.120^{\circ} \mathrm{C}\right)$ and four reaction times $(30,60,90$ and $100 \mathrm{~min})$ at a solid to liquid ratio of 1:10 (w/w) (based on total solid) in a $500 \mathrm{~mL}$ Erlenmeyer flasks with a working volume of $100 \mathrm{ml}$. After dilute acid hydrolysis, the 
flask was cooled in an ice bath, and the hydrolysate was separated from the solid by filtration. The hydrolysate was then analyzed for its reducing sugar content by using by 3,5-dinitrosalicylic acid method using glucose as the standard following Miller's method [34].

\subsection{Fermentation}

Reducing sugars produced after acid hydrolysis of $\mathrm{KW}$ were subjected to fermentation using fungal and bacterial strains i.e. Aspergillus Niger FCBP-0198, Lacto-bacillus FCBP-0004 and Escherichia coli FCBP0011 without adding of any nutrient components. After the adjustment of $\mathrm{pH}$ to 6.5 using $5 \mathrm{M} \mathrm{NaOH}, \mathrm{a}$ final volume $100 \mathrm{~mL}$ of hydrolysates in $250 \mathrm{ml}$ Erlenmeyer flasks was fermented with $2 \%(\mathrm{v} / \mathrm{v})$ of Aspergillus Niger FCBP-0198, Lacto-bacillus FCBP-0004 and Escherichia coli FCBP-00. The flasks were sealed with a rubber stopper. These three flasks were incubated in laboratory incubator (Wise Cube WIG105) at $25^{\circ} \mathrm{C}$ (Aspergillus Niger), $37^{\circ} \mathrm{C}$ (Lacto-bacillus) and $37^{\circ} \mathrm{C}$ (Escherichia coli) for 7 days by using separate hydrolysis and fermentation. Reducing sugar concentration was measured after every day by collecting $20 \mathrm{ml}$ liquid of samples in the flasks, for continuously monitoring of the fermentation substrate. All fermentation experiments were performed with three replicates.

\subsection{Analytical methods}

The preparation of samples for GCMS and analysis procedure is explained elsewhere [35]. In summary, the fermented product was dried under nitrogen flow and passed through magnesium sulphate column to remove any moisture contents. The dried contents then dissolved in cyclohexane and send for GCMS analysis. A Hewlett-Packard (HP) 5973 Mass Selective Detector (MSD) interfaced to a HP 6890N gas chromatograph (GC) with $30 \mathrm{~m} \times 0.25 \mathrm{~mm}$ ID capillary column (DB-5 MS, J \& W scientific) was used for the analysis. GC-MS analysis was performed on sample before and after fermentation to identify and quantify the compound present in sample. Calorific value of before and after fermentation was also measured using Differential Scanning Calorimeter (DSC-6000, Perkin Elmer) [36].

\subsection{Statistical analysis}

Statistical analysis of the results was carried out by two-way ANOVA analysis and Tukey's test using Minitab software Version 17.0. Tukey's test was used to compare the significance between the means of results at the $95 \%$ confidence level $(p<0.05)$.

\section{Results And Discussion}

\subsection{Acid hydrolysis}

The use of low cost and abundantly available $\mathrm{KW}$ is presently being recognized as raw material for the production of bio-fuel because it contains significant amount of carbohydrates and lipid [37]. Moreover, it also has abundant nutrition, high moisture and organic component. Their key advantages are their abundance, diversity and low cost [38]. KW used in this study was composed of cellulose (insoluble carbohydrate), hemicelluloses, lignin, proteins, fat etc. Hydrolysis of KW was performed to convert 
polysaccharides into monosaccharide i.e. reducing sugars, lipids to fatty acids and proteins to amino acids. Optimization of various parameters for hydrolysis was done for maximum reducing sugar production.

The dilute acid hydrolysis was performed using $1 \%, 3 \%$ and $5 \%(\mathrm{w} / \mathrm{w})$ sulfuric acid at different temperatures $\left(90^{\circ} \mathrm{C}\right.$ and $\left.120^{\circ} \mathrm{C}\right)$ and reaction times $(30,60,90$ and $120 \mathrm{~min})$. The dilute acid hydrolysis conditions, reducing sugars and energy released from $\mathrm{KW}$ are summarized in Table 2 . The dilute acid hydrolysis conditions were selected after a series of preliminary experiments. As shown in Table 2 at constant acid concentration and temperature, reducing sugars were increased by increasing the reaction time. Through the dilute acid hydrolysis with $1 \%$ acid at $120^{\circ} \mathrm{C}$ for 120 minutes, $61.287 \pm 0.2 \mathrm{~g}$ of reducing sugars were released from each $\mathrm{kg}$ of $\mathrm{KW}$ and $0.981 \pm 0.004 \mathrm{MJ}$ energy was produced from each $\mathrm{kg}$ of $\mathrm{KW}$. By increasing the temperature to $120^{\circ} \mathrm{C}$ from $90^{\circ} \mathrm{C}$ and reaction time to $120 \mathrm{~min}$ at $1 \%$ acid concentration, release of reducing sugars and energy are increasing. At the temperature of $90^{\circ} \mathrm{C}$, when the acid concentration was increased to $3 \%$, maximum release of reducing sugars was $62.483 \pm 1.5$ from each $\mathrm{kg}$ of KW and production of energy was $1.000 \pm 0.025$ from each $\mathrm{kg}$ of $\mathrm{KW}$ for 120 minutes. Reducing sugars and energy values at $3 \%$ acid concentration at $120^{\circ} \mathrm{C}$ for 120 minutes are higher than the previous ones it shows that increase in concentration of acid cause increase in production of reducing sugars and energy from each $\mathrm{kg}$ of $\mathrm{KW}$. Whereas, increasing the reaction time to $120 \mathrm{~min}$ increased $20.747 \mathrm{~g}$ reducing sugars and $0.332 \mathrm{MJ}$ energy from each $\mathrm{kg}$ of $\mathrm{KW}$. The highest amount of reducing sugars and energy was detected after treatment with $5 \%$ acid concentration at $120^{\circ} \mathrm{C}$ for 120 min. At $5 \%$ acid concentration by increasing temperature to $120^{\circ} \mathrm{C}$ and reaction time to 120 minutes release of reducing sugars and energy are increasing and maximum $97.917 \pm 0.5$ of reducing sugars from each $\mathrm{kg}$ of $\mathrm{KW}$ and $1.567 \pm 0.008 \mathrm{MJ}$ of energy from each $\mathrm{kg}$ of $\mathrm{KW}$ was achieved. Similarly, V. Gupta et al. [39] observed $19.1 \%$ reducing sugars in dilute acid hydrolysis by sulfuric acid $(0.5 \% \mathrm{v} / \mathrm{v})$ at $120^{\circ} \mathrm{C}$ for $60 \mathrm{~min}$ of rice straw. Jain et al. [40] carried out dilute sulfuric acid pretreatment and resulted in releasing of $12.52 \%$ reducing sugars using rice straw as raw material. Kshirsagar et al. [41] resulted release of $0.359 \mathrm{~g} / \mathrm{g}$ reducing sugars after $72 \mathrm{~h}$ saccharification of $0.5 \%$ dilute sulfuric acid pretreated rice straw at $120^{\circ} \mathrm{C}$, for $60 \mathrm{~min}$. 
Table 2

Reducing sugars and Energy at different parameters of acid hydrolysis of KW

\begin{tabular}{|c|c|c|c|c|}
\hline $\begin{array}{l}\text { Acid Concentration } \\
(\% \mathrm{w} / \mathrm{w})\end{array}$ & $\begin{array}{l}\text { Temperature } \\
\left({ }^{\circ} \mathrm{C}\right)\end{array}$ & $\begin{array}{l}\text { Time } \\
(\min )\end{array}$ & $\begin{array}{l}\text { Reducing sugars } \\
(\mathrm{g} / \mathrm{kg})\end{array}$ & $\begin{array}{l}\text { Energy } \\
(\mathrm{MJ} / \mathrm{kg})\end{array}$ \\
\hline \multirow[t]{8}{*}{1} & \multirow[t]{4}{*}{90} & 30 & $37.673 \pm 0.3$ & $0.603 \pm 0.005$ \\
\hline & & 60 & $43.613 \pm 0.4$ & $0.698 \pm 0.006$ \\
\hline & & 90 & $48.047 \pm 0.9$ & $0.769 \pm 0.016$ \\
\hline & & 120 & $53.850 \pm 0.7$ & $0.862 \pm 0.013$ \\
\hline & \multirow[t]{4}{*}{120} & 30 & $41.300 \pm 0.4$ & $0.661 \pm 0.008$ \\
\hline & & 60 & $46.197 \pm 1.3$ & $0.739 \pm 0.021$ \\
\hline & & 90 & $55.830 \pm 0.4$ & $0.893 \pm 0.007$ \\
\hline & & 120 & $61.287 \pm 0.2$ & $0.981 \pm 0.004$ \\
\hline \multirow[t]{8}{*}{3} & \multirow[t]{4}{*}{90} & 30 & $48.980 \pm 0.3$ & $0.784 \pm 0.006$ \\
\hline & & 60 & $56.933 \pm 0.8$ & $0.911 \pm 0.014$ \\
\hline & & 90 & $59.697 \pm 0.8$ & $0.955 \pm 0.013$ \\
\hline & & 120 & $62.483 \pm 1.5$ & $1.000 \pm 0.025$ \\
\hline & \multirow[t]{4}{*}{120} & 30 & $51.407 \pm 0.5$ & $0.823 \pm 0.008$ \\
\hline & & 60 & $58.023 \pm 0.5$ & $0.928 \pm 0.009$ \\
\hline & & 90 & $64.430 \pm 0.6$ & $1.031 \pm 0.010$ \\
\hline & & 120 & $69.727 \pm 0.6$ & $1.116 \pm 0.011$ \\
\hline \multirow[t]{8}{*}{5} & \multirow[t]{4}{*}{90} & 30 & $55.107 \pm 1.0$ & $0.882 \pm 0.017$ \\
\hline & & 60 & $61.673 \pm 0.8$ & $0.987 \pm 0.013$ \\
\hline & & 90 & $66.497 \pm 0.4$ & $1.064 \pm 0.007$ \\
\hline & & 120 & $77.857 \pm 0.5$ & $1.246 \pm 0.009$ \\
\hline & \multirow[t]{4}{*}{120} & 30 & $74.537 \pm 0.7$ & $1.193 \pm 0.011$ \\
\hline & & 60 & $81.087 \pm 0.6$ & $1.297 \pm 0.010$ \\
\hline & & 90 & $93.203 \pm 0.6$ & $1.491 \pm 0.011$ \\
\hline & & 120 & $97.917 \pm 0.5$ & $1.567 \pm 0.008$ \\
\hline
\end{tabular}


In the present study, dilute sulfuric acid hydrolysate was fermented by Fungus and bacterial species i.e. Aspergillus Niger FCBP-0198, Lacto-bacillus FCBP-0004 and Escherichia coli FCBP-001 to convert reducing sugars in bio-fuel. During fermentation of $72 \mathrm{~h}$ change in concentration of reducing sugars was calculated after every 24 hours as shown in Fig. 1. The amount of reducing sugars of KW fermented by Aspergillus Niger, Lacto-bacillus and Escherichia coli for $72 \mathrm{~h}$ showed that with the passage of time the amount of reducing sugars decreased. About $64 \%$ reducing sugar was converted into hydrocarbons after fermentation of KW by Aspergillus Niger while conversion of reducing sugar into hydrocarbons after fermentation of KW by Lacto-bacillus and Escherichia coli was $45 \%$ and $50 \%$ respectively as shown in Fig. 2. It indicates that Aspergillus Niger has more potential for conversion of reducing sugars in hydrocarbons as compare to Lacto-bacillus and Escherichia coli. Overall, maximum percentage of hydrocarbons from KW was produced after fermentation by Aspergillus Niger.

\subsection{GC-MS analysis}

After fermentation process samples were analyzed on GC-MS to identify and quantify the compound present in samples before and after fermentation by Aspergillus Niger, Escherichia coli and Lacto bacillus. Figure 2 shows the peaks of compounds in KW after and before fermentation. Nine different compounds were identified in $\mathrm{KW}$ before fermentation and 12 hydrocarbons were identified after fermentation. Figure 2 shows the compounds that were present in KW. These compounds are mostly hydrocarbons and can be used as biofuel. $5-8 \mathrm{~g}$ of $\mathrm{HC}$ were produced per $\mathrm{Kg}$ of $\mathrm{KW}$.

\subsection{Calorific value of samples}

Calorific values of sample before and after fermentation by different strains were determined. Table 3 shows the calorific value of $\mathrm{KW}$ before fermentation i.e. $0.6 \mathrm{MJ} / \mathrm{kg}$ and calorific value of $\mathrm{KW}$ fermented by Aspergillus Niger, Escherichia coli and Lacto-bacillus are 3.56, 3.34 and $2.67 \mathrm{MJ} / \mathrm{kg}$. Maximum calorific value i.e. $3.56 \mathrm{MJ} / \mathrm{kg}$ was achieved by $\mathrm{KW}$ fermented by Aspergillus Niger. This calorific value of biofuel is before distillation process. So, this value will be improved after distillation.

\section{Table-3: Quantification of Hydrocarbons produced in Biofuel from KW.}




\begin{tabular}{|lll|}
\hline Peak I.D. & Compound & $\begin{array}{l}\text { Absolute Concentration } \\
\text { (g of HC/Kg of KW) }\end{array}$ \\
\hline 1 & Methyl alcohol & 6.76 \\
\hline 2 & Oxalic acid & 5.07 \\
\hline 3 & 2-Methyl Pentane & 8.45 \\
\hline 4 & 3-Methyl Pentane & 6.76 \\
\hline 5 & 2,2-Dimethyl Pentane & 5.07 \\
\hline 6 & 4-Methyl 1-Pentol & 8.45 \\
\hline 7 & 3,3-Dimethyl Pentane & 6.76 \\
\hline 8 & 2-Methyl Hexane & 5.07 \\
\hline 9 & 3-Methyl Hexane & 8.45 \\
\hline 10 & 2,2,3,3-Tetramethyl Butane & 6.76 \\
\hline 11 & 2,3-Dimethyl Hexane & 5.07 \\
\hline
\end{tabular}

\subsection{Literature comparison}

A literature comparison of biofuel calorific values of present study with reported literature values was also done [38] (Table-4). It shows the calorific values of biofuel fermented from different waste streams. Due to pre-treatment and acid hydrolysis, the production of biofuel in enhanced quite much which in indicated by the high calorific values of $\mathrm{KW}$ fermentation it is because the other waste was direct fermented to produce biofuel while for KW methodology was modified by doing pretreatment and acid hydrolysis that will increasing the chance for conversion of reducing sugars into biofuel.

Table-4: Calorific value of various samples imported in literature (Biofuels \& Biomass 2007) 


\begin{tabular}{|c|c|}
\hline Raw material & Calorific value (MJ/kg) \\
\hline \multirow[t]{3}{*}{ Kitchen waste (Present Study) } & 3.56 (A. Niger) \\
\hline & 3.34 (E. Coli) \\
\hline & 2.67 (L. Curvatus) \\
\hline Forest wood chip fresh & 0.718 \\
\hline Miscanthus & 1.580 \\
\hline Rape seed & 2.453 \\
\hline Stover rapeseed & 1.496 \\
\hline Sunflower & 1.998 \\
\hline Wheat & 1.496 \\
\hline
\end{tabular}

\section{Conclusions}

The KW was used as source to produce biofuel. The acid hydrolysis produced maximum of $37.673 \mathrm{~g}$ reducing sugars per each $\mathrm{kg}$ of $\mathrm{KW}$ under optimum conditions i.e. $5 \%$ acid concentration for 2 hours at $120^{\circ} \mathrm{C}$. A maximum of $64 \%$ reducing sugars were converted into hydrocarbons (biofuel) after fermentation by Aspergillus Niger. GCMS analysis showed that the reducing sugars were converted into hydrocarbons having good calorific values i.e. $3.65 \mathrm{MJ} / \mathrm{Kg}$.

\section{Declarations}

\section{ACKNOWLEDMENT}

Authors are thankful to Punjab University for providing bacterial and fungal strains along with Calorific value analysis. Authors are also thankful to Pakistan Council of Scientific and Industrial Research for providing GC-MS facility.

\section{References}

1. Goldemberg, J., Ethanol for a sustainable energy future. science, 2007. 315(5813): p. 808-810.

2. Borines, M.G., R.L. de Leon, and J.L. Cuello, Bioethanol production from the macroalgae< i> Sargassum</i> spp. Bioresource technology, 2013. 138: p. 22-29.

3. Vavouraki, A.I., E.M. Angelis, and M. Kornaros, Optimization of thermo-chemical hydrolysis of kitchen wastes. Waste Management, 2013. 33(3): p. 740-745.

4. Balat, M., H. Balat, and C. Öz, Progress in bioethanol processing. Progress in energy and combustion science, 2008. 34(5): p. 551-573. 
5. Crabbe, E., et al., Biodiesel production from crude palm oil and evaluation of butanol extraction and fuel properties. Process biochemistry, 2001. 37(1): p. 65-71.

6. Dizge, N. and B. Keskinler, Enzymatic production of biodiesel from canola oil using immobilized lipase. Biomass and Bioenergy, 2008. 32(12): p. 1274-1278.

7. Ma, F., L.D. Clements, and M.A. Hanna, Biodiesel fuel from animal fat. Ancillary studies on transesterification of beef tallow. Industrial \& engineering chemistry research, 1998. 37(9): p. 37683771.

8. Zhang, Y., et al., Biodiesel production from waste cooking oil: 1. Process design and technological assessment. Bioresource technology, 2003. 89(1): p. 1-16.

9. Talebnia, F., D. Karakashev, and I. Angelidaki, Production of bioethanol from wheat straw: an overview on pretreatment, hydrolysis and fermentation. Bioresource technology, 2010. 101(13): p. 4744-4753.

10. Abbas, A. and S. Ansumali, Global potential of rice husk as a renewable feedstock for ethanol biofuel production. Bioenergy Research, 2010. 3(4): p. 328-334.

11. Khola, G. and B. Ghazala, Biodiesel production from algae. Pak J Bot, 2012. 44(1): p. 379-381.

12. Haydar, S. and J. Masood, Evaluation of Kitchen Waste Composting and its Comparison with Compost Prepared from Municipal Solid Waste. Pak. J. Engg. \& Appl. Sci. Vol, 2011: p. 26-33.

13. Haydar, S. and J. Masood, Evaluation of kitchen waste composting and its comparison with compost prepared from municipal solid waste. Pakistan Journal of Engineering and Applied Sciences, 2016.

14. Uncu, O.N. and D. Cekmecelioglu, Cost-effective approach to ethanol production and optimization by response surface methodology. Waste management, 2011. 31(4): p. 636-643.

15. Karmee, S.K. and C.S.K. Lin, Valorisation of food waste to biofuel: current trends and technological challenges. Sustainable Chemical Processes, 2014. 2(1): p. 1-4.

16. Hong, Y., et al. Ethanol Production from Food Wastes. in The 31st Symposium on Biotechnology for Fuels and Chemicals. 2009.

17. Adhikari, B.K., S. Barrington, and J. Martinez, Predicted growth of world urban food waste and methane production. Waste Management \& Research, 2006. 24(5): p. 421-433.

18. Palmisano, A.C. and M.A. Barlaz, Microbiology of solid waste. Vol. 3. 1996: CRC press.

19. Hong, Y.S. and H.H. Yoon, Ethanol production from food residues. Biomass and Bioenergy, 2011. 35(7): p. 3271-3275.

20. Matsakas, L., et al., Utilization of household food waste for the production of ethanol at high dry material content. Biotechnology for biofuels, 2014. 7(1): p. 1-9.

21. Sun, Y. and J. Cheng, Hydrolysis of lignocellulosic materials for ethanol production: a review. Bioresource technology, 2002. 83(1): p. 1-11.

22. Esteghlalian, A., et al., Modeling and optimization of the dilute-sulfuric-acid pretreatment of corn stover, poplar and switchgrass. Bioresource Technology, 1997. 59(2): p. 129-136. 
23. McMillan, J.D. Pretreatment of lignocellulosic biomass. in ACS symposium series (USA). 1994.

24. Del Campo, I., et al., Diluted acid hydrolysis pretreatment of agri-food wastes for bioethanol production. Industrial Crops and Products, 2006. 24(3): p. 214-221.

25. Wijaya, Y.P., et al., Comparative study on two-step concentrated acid hydrolysis for the extraction of sugars from lignocellulosic biomass. Bioresource technology, 2014. 164: p. 221-231.

26. Limayem, A. and S.C. Ricke, Lignocellulosic biomass for bioethanol production: current perspectives, potential issues and future prospects. Progress in energy and combustion science, 2012. 38(4): p. 449-467.

27. Rocha, N.R.d.A.F., et al., Ethanol production from agroindustrial biomass using a crude enzyme complex produced by Aspergillus niger. Renewable Energy, 2013. 57: p. 432-435.

28. Dien, B.S., et al., Development of new ethanologenic Escherichia coli strains for fermentation of lignocellulosic biomass. Applied biochemistry and biotechnology, 2000. 84(1): p. 181-196.

29. Sakai, K. and T. Yamanami, Thermotolerant Bacillus licheniformis TY7 produces optically active Llactic acid from kitchen refuse under open condition. J Biosci Bioeng, 2006. 102(2): p. 132-134.

30. Akao, S., H. Tsuno, and J. Cheon, Semi-continuous L-lactate fermentation of garbage without sterile condition and analysis of the microbial structure. Water Res, 2007. 41(8): p. 1774-1780.

31. Yan, S., et al., Enzymatical hydrolysis of food waste and ethanol production from the hydrolysate. Renewable Energy, 2011. 36(4): p. 1259-1265.

32. Sakai, K., et al., Selective proliferation of lactic acid bacteria and accumulation of lactic acid during open fermentation of kitchen refuse with intermittent $\mathrm{pH}$ adjustment. Food science and technology research, 2007. 6(2): p. 140-145.

33. Shin, H.-S., J.-H. Youn, and S.-H. Kim, Hydrogen production from food waste in anaerobic mesophilic and thermophilic acidogenesis. International Journal of Hydrogen Energy, 2004. 29(13): p. 13551363.

34. Miller, G.L., Use of dinitrosalicylic acid reagent for determination of reducing sugar. Analytical chemistry, 1959. 31(3): p. 426-428.

35. Jalees, M.I., F. Tahira, and H. Saleem, Study on the geochemical correlation of crude oils of Palaeocene and Jurassic ages from the Potowar Indus Basin in northern Pakistan. Chinese Journal of Geochemistry, 2010. 29(1): p. 82-93.

36. Kumar, J.V. and B.C. Pratt, Determination of calorific values of some renewable biofuels. Thermochimica Acta, 1996. 279: p. 111-120.

37. $\mathrm{Ma}, \mathrm{H}$., et al., The utilization of acid-tolerant bacteria on ethanol production from kitchen garbage. Renewable Energy, 2009. 34(6): p. 1466-1470.

38. Biofuels \& Biomass. biofuelsb2b. 2007 [cited 2016 June 6,]; Available from: http://www.biofuelsb2b.com/.

39. Gupta, V., V.V. Thakur, and R. Jain, Dilute acid hydrolysis of rice straw for efficient recovery of xylose. J. Env. Res., 2016. 4: p. 307-311. 
40. Jain, R.K., et al., Ethanol production from rice straw using thermotolerant Kluyveromyces sp. IIPE453. Biomass Conversion and Biorefinery, 2015. 5(4): p. 331-337.

41. Kshirsagar, S.D., et al., Dilute acid pretreatment of rice straw, structural characterization and optimization of enzymatic hydrolysis conditions by response surface methodology. RSC Advances, 2015. 5(58): p. 46525-46533.

\section{Figures}

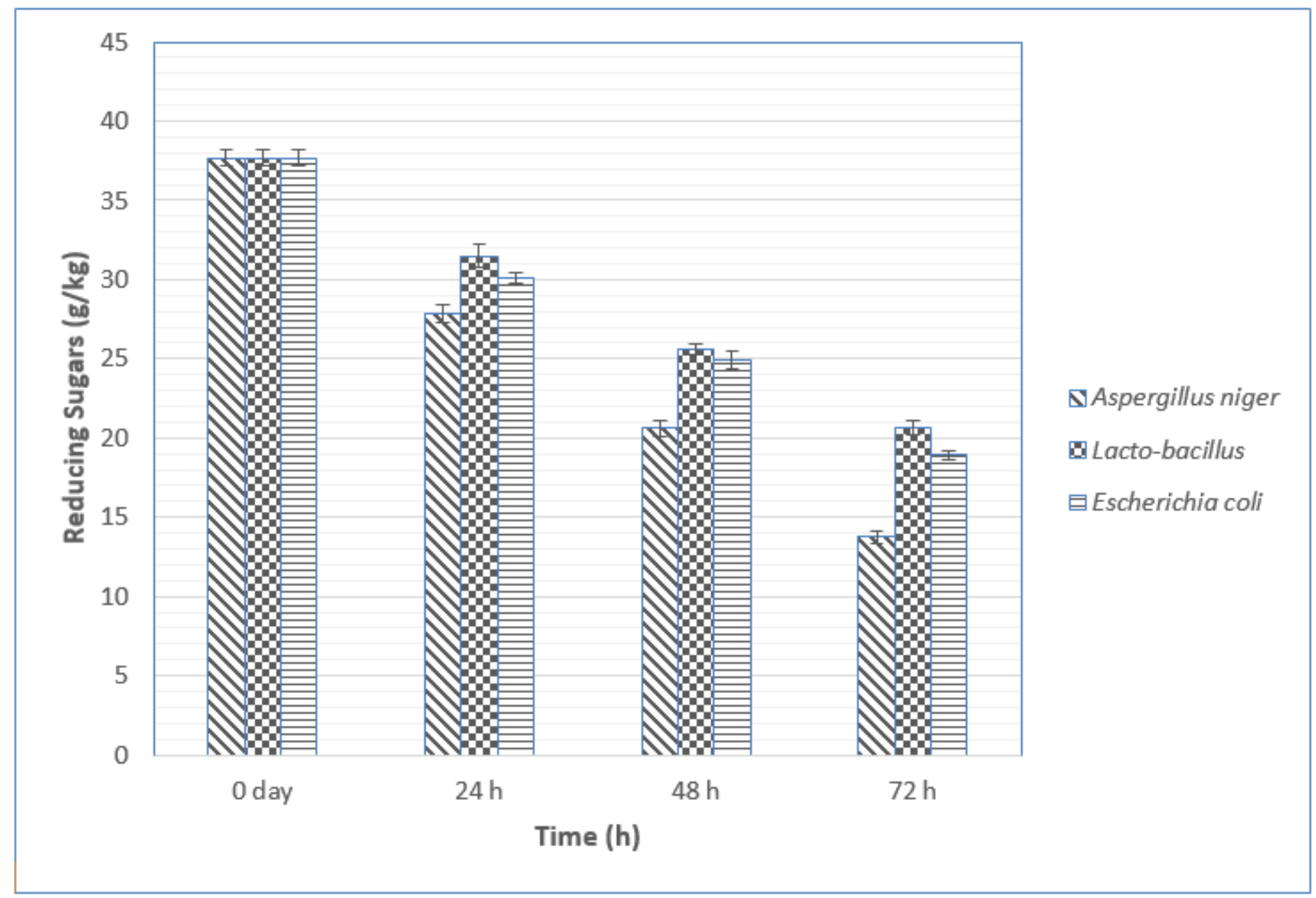

\section{Figure 1}

1 Reducing sugars during $72 \mathrm{~h}$ of fermentation of KW by Aspergillus niger, Lacto-bacillus and Escherichia coli 

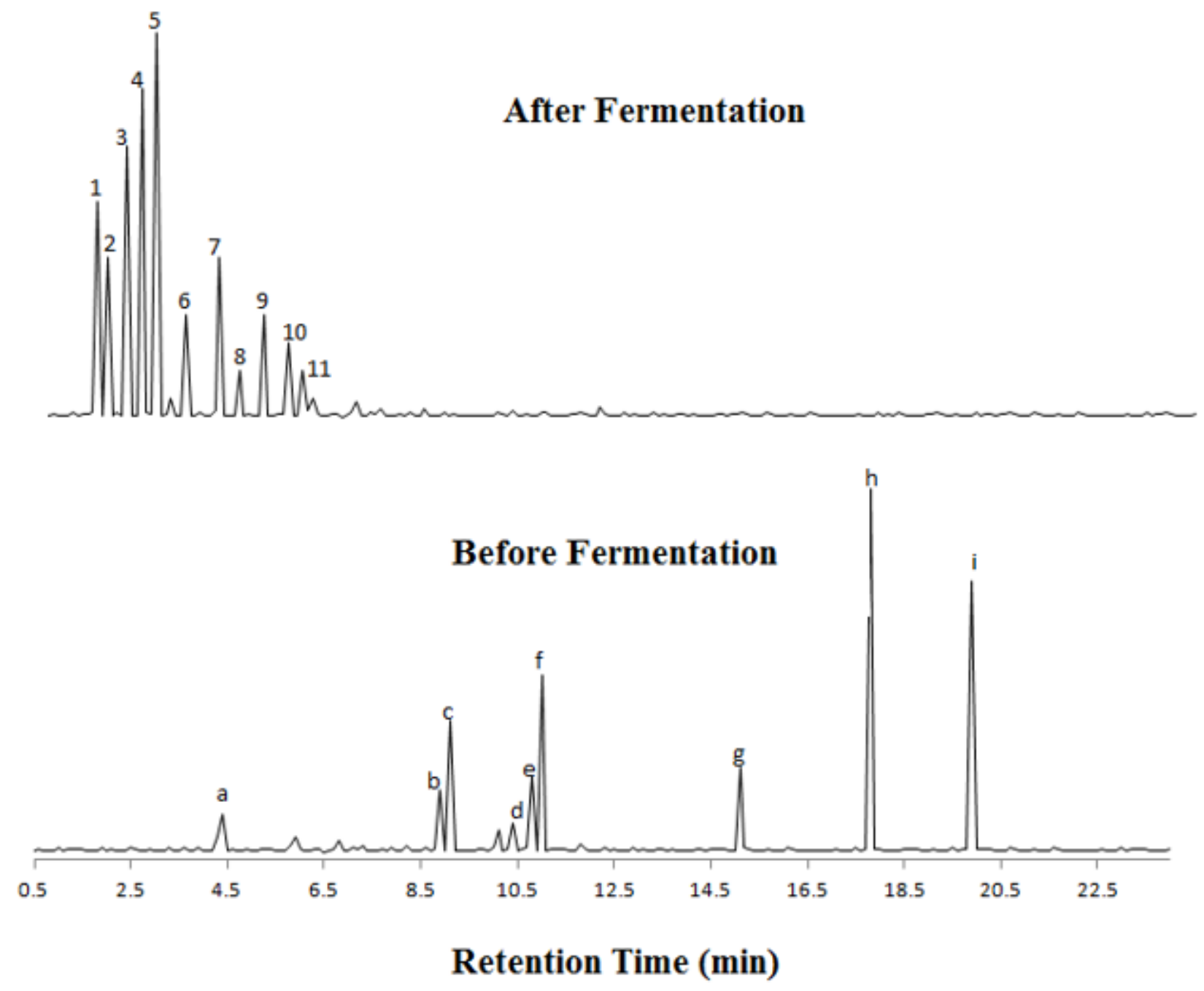

Figure 2

GCMS Analysis of fermentation products of Aspergillus niger used for Sample-1. Peaks are labeled i.e. a: furfural; b: 2,5-Furan dicarboxaldehyde; c: Levoglucosenone; d: 2,4-Decadieral (R); e: 2,4-Decadieral (S); f: 2-Furancarboxaldehyde; 5-(hydroxymethyl); g: D-Allose, h; n-Hexadecanoic acid; i: Octadec-9-enoic acid; 1: Methyl alcohol; 2: Oxalic acid; 3: 2-Methyl Pentane; 4: 3-Methyl Pentane; 5: 2,2-Dimethyl Pentane; 6: 4Methyl 1-Pentol; 7: 3,3-Dimethyl Pentane; 8: 2-Methyl Hexane; 9: 3-Methyl Hexane; 10: 2,2,3,3-Tetramethyl Butane; 11: 2,3-Dimethyl Hexane 